\title{
Public Perception About Pandemic Risk
}

\author{
Baiq Liana Widiyanti \\ Universitas Hamzanwadi \\ baiqlianawidiyanti@hamzanwadi.ac.id
}

\section{Article History}

accepted 31/08/2020

approved 22/09/2020

published 28/10/2020

\begin{abstract}
This research motivated by the prevalence of the pandemic myth, namely that a pandemic is unavoidable and thus nothing to be worried about, and the health sector which should manage risks, and the risk of a pandemic, is not a development problem. This will lead to a poor understanding of pandemic risks, minimal preparedness and inadequate prevention. Examining the reasons this myth persists can help improve risk management associated with pandemics. Perceptions of risk play an important role in shaping health-related behaviors in controlling infectious diseases. The aim of this study is to assess risk perceptions and behavioral changes in response to a pandemic. This research is a qualitative research, with descriptive analysis techniques. The results showed that most people were apathetic in responding to pandemic conditions.
\end{abstract}

Keywords: pandemic, public perceptions, risk management

\section{Abstrak}

Penelitian ini dimotivasi oleh prevalensi mitos pandemik, yaitu pandemi tidak dapat dihindari dan dengan demikian tidak perlu dikhawatirkan, dan sektor kesehatan yang seharusnya mengelola risiko, serta risiko pandemi bukanlah masalah pembangunan. Hal ini akan mengarah pada rendahnya pemahaman mengenai risiko pandemi, kesiapan yang minim, dan pencegahan yang tidak memadai. Meneliti alasan mengapa mitos ini bertahan dapat membantu meningkatkan manajemen risiko yang terkait dengan pandemik. Persepsi mengenai risiko memainkan peran penting dalam membentuk perilaku yang berhubungan dengan kesehatan dalam pengontrolan terhadap penyakit menular. Tujuan dari penelitian ini adalah untuk menilai persepsi risiko dan perubahan perilaku dalam menanggapi pandemik. Penelitian ini merupakan penelitian kualitatif, dengan teknik analisis deskriptif. Hasil penelitian menunjukkan bahwa sebagian besar masyarakat bersifat apatis dalam merespon kondisi pandemik.

Kata kunci: manajemen risiko, pandemic, persepsi masyarakat

Social, Humanities, and Education Studies (SHEs): Conference Series https://jurnal.uns.ac.id/shes 


\section{PENDAHULUAN}

Isu terkini dan menggemparkan selalu mendapatkan perhatian publik dengan beragam reaksi persepsi dan tingkah lakunya, isu wabah virus corona atau Covid-19 juga tidak terlepas dari fenomena ini. Beragam persepsi atau sudut pandang masyarakat juga dapat dianggap sebagai aktivitas menyuarakan ide atau pengetahuan yang dimiliki mengenai krisis yang sedang dihadapi (Pranita, 2020). Masyarakat memahami bahwa pandemi Covid-19 disebabkan oleh virus yang baru ditemukan, yaitu SARS-CoV-2 (Assessment, 2018; Otálora, 2020). Penyakit ini menular melalui droplet atau percikan cairan hidung dan mulut penderita kepada orang lain di sekitarnya (Gostic, Gomez, Mummah, Kucharski, \& Lloyd-Smith, 2020; Rothan \& Byrareddy, 2020). Beberapa gejala umum yang digunakan sebagai penanda seseorang terinfeksi virus Corona, yaitu: demam (suhu tubuh di atas $38^{\circ} \mathrm{C}$ ), batuk, serta sesak napas (Bai et al., 2020; Lohiniva, Sane, Sibenberg, Puumalainen, \& Salminen, 2020; Organization, 2020).

Tingginya angka perebakan virus corona serta peningkatan jumlah kasus merupakan indikasi rendahnya persepsi masyarakat akan risiko virus tersebut (Buana, 2017; Gallotti, Valle, Castaldo, Sacco, \& De Domenico, 2020; Kamel Boulos \& Geraghty, 2020; Shammi, Bodrud-Doza, Towfiqul Islam, \& Rahman, 2020). Salah satu faktor yang dapat memperlambat, bahkan memperburuk, penanganan persebaran Covid-19 adalah anakronisme perspektif yang beredar luas di masyarakat. Anakronisme perspektif yang berkembang di masyarakat, yaitu cara pandang yang kurang tepat dalam menyikapi dan merespons persebaran virus (Hilmy, 2020). Hal ini juga disinyalir disebabkan oleh kurang kuatnya pesan dan informasi yang disampaikan pemerintah kepada masyarakat (Ahmad et al., 2020; Dani \& Mediantara, 2020; Gallotti et al., 2020; Rogers et al., 2020; Shook, Sevi, Lee, Oosterhoff, \& Fitzgerald, 2020). Hal inilah yang mendasari dilakukannya penelitian dengan tema persepsi masyarakat mengenai risiko pandemi seperti pandemi yang terjadi sekarang ini.

\section{METODE}

Penelitian ini merupakan penelitian kualitatif dengan menggunakan analisis deskriptif kualitatif terhadap penelitian yang telah ada mengenai persepsi masyarakat terkait pandemic. Penelitian ini dilakukan studi pustaka atau kajian literatur. Yang menjadi fokus utama kajian adalah: (a) konsep penyakit menular, wabah, epidemic, pandemik, serta mitos-mitos yang berkembang terkait pandemic; (b) Konsep mengenai persepsi, dan faktor yang mempengaruhinya, serta (c) peranan media dalam pembentukan persepsi.

\section{HASIL DAN PEMBAHASAN}

Pembahasan dalam paper ini dibagi menjadi 3 sub bab untuk memberikan gambaran komprehenesif mengenai persespsi masyarakat terkait risiko pandemik.

\section{Penyakit Menular, Wabah, Epidemik, Pandemik, dan Mitos terkait Pandemik}

Organisasi Kesehatan Dunia (WHO) mengumumkan Covid-19 sebagai pandemi global pada 11 Maret 2020. Dimulai dengan rantai kecil penyebaran, yang selanjutnya mencapai puncaknya menjadi rantai penyebaran yang lebih besar di banyak negara mengakibatkan transmisi penyebarannya mempengaruhi semua benua di seluruh dunia (Anderson, Heesterbeek, Klinkenberg, \& Hollingsworth, 2020). Pandemi adalah satu epidemi (kejadian penyakit di atas normal yang diharapkan) yang menyerang setidaknya beberapa negara di lebih dari satu benua (Olga, 2014). Dikutip dari Kamus Besar Bahasa Indonesia atau KBBI (Bahasa, 2016), pandemi adalah wabah yang berjangkit serempak di mana-mana atau meliputi geografi yang luas. Hal ini 
menunjukkan bahwa virus Corona telah diakui menyebar luas hampir ke seluruh dunia. WHO sendiri mendefinisikan pandemi sebagai situasi ketika populasi seluruh dunia ada kemungkinan akan terkena infeksi ini dan berpotensi sebagian dari mereka jatuh sakit.

Ada beberapa mitos yang berkembang serta diyakini secara luas mengenai pandemik, yaitu: bahwa pandemi tidak dapat dihindari dan dengan demikian tidak perlu dikhawatirkan; sektor kesehatan yang akan mengelola risiko, serta risiko pandemi bukanlah masalah pembangunan (Assessment, 2018; Liliana Cori 1, * \& Anthonj, 1993; Seale et al., 2020). Hal ini mengarah pada terlalu rendahnya risiko pandemi, kesiapan yang minim, dan pencegahan yang tidak memadai. Mengkaji alasan mengapa mitos ini bertahan dapat membantu pemerintah dan organisasi internasional meningkatkan manajemen risiko yang terkait dengan pandemi.

Pandemi mungkin tampak terutama sebagai masalah kesehatan saja, tetapi hal ini sebenarnya menyesatkan. Berfokus pada dampak kesehatan saja akan membuat orang dan pemerintah meremehkan total risiko dan mengabaikan kebijakan, pencegahan, dan tindakan kesiapsiagaan untuk meningkatkan ketahanan dan memungkinkan kelangsungan bisnis dan kehidupan domestik masyarakat secara umum (Dai, 2020; Sampurno, Kusumandyoko, \& Islam, 2020; Shammi et al., 2020). Hal inilah yang menjadikan manajemen risiko menjadi sangat penting.

Risiko pandemi adalah nilai yang diharapkan dari dampak penyebaran penyakit menular pada manusia terhadap kesehatan manusia, ekonomi, dan masyarakat (Olga, 2014). Meskipun penyakit menular merupakan bahaya alam, pandemi adalah bencana yang sebagian besar disebabkan oleh ulah manusia. Begitu upaya manusia untuk menghentikan penularan dini terbukti tidak memadai dan pandemi dimulai, sebagian besar bencana akan muncul dari perilaku manusia yang mengganggu sistem ekonomi dan sosial yang saling berhubungan (Currie et al., 2020; Jones et al., 2008).

\section{Konsep Mengenai Persepsi dan Faktor yang Mempengaruhinya}

Persepsi adalah suatu proses dimana individu mengorganisasikan dan menginterpretasikan kesan sensori mereka untuk memberi arti pada lingkungan mereka. Persepsi juga merupakan proses kognitif yang memungkinkan kita dapat menafsirkan dan memahami lingkungan sekitar (Robbins, 2002). Persepsi masyarakat tentang bahaya biologis memainkan peran kunci dalam tanggap darurat kesehatan, yang mempengaruhi manajemen risiko dan strategi komunikasi risiko. Oleh karena itu, persepsi masyarakat mengenai risiko kesehatan dapat mempengaruhi pasar, kebijakan publik, dan perilaku individu sebagai bagian dari masyarakat (Motta Zanin, Gentile, Parisi, \& Spasiano, 2020)

Persepsi risiko dengan demikian penting untuk tindakan pencegahan, tetapi persepsi risiko sering bias. Optimisme yang tidak realisitis tentang risiko kesehatan mengakibatkan kurangnya tindakan pencegahan dan perasaan aman palsu. Faktor yang dapat mempengaruhi kemauan dan motivasi untuk melakukan tindakan preventif adalah persepsi risiko (de Zwart, Veldhuijzen, Richardus, \& Brug, 2010; Liliana Cori 1, * \& Anthonj, 1993; Massaro, Ganin, Perra, Linkov, \& Vespignani, 2018; Seale et al., 2020; Sjöberg, 2000). Persepsi risiko termasuk dalam kategori psikologi, yang mengacu pada persepsi individu dan pemahaman tentang berbagai bahaya secara objektif (Ding et al., 2020; Shammi et al., 2020). Persepsi risiko merupakan faktor penting yang mempengaruhi perilaku berisiko. Orang dengan persepsi risiko lebih rendah cenderung mengambil perilaku berisiko atau mengurangi perilaku pencegahan, sedangkan orang dengan persepsi risiko tinggi cenderung mengambil perilaku preventif. Faktor -faktor yang mempengaruhi persepsi risiko adalah: sensitivitas terhadap risiko, sikap dan ketakutan khusus (Sjöberg, 2000).

Perilaku individu dipengaruhi oleh persepsi dan kepercayaan individu tersebut tanpa memandang apakah persepsi dan kepercayaan tersebut sesuai atau tidak 
sesuai dengan realitas. Penilaian secara subyektif inilah yang paling sering dijumpai dalam masyarakat (Priyoto, 2014). Teori Health Belief Models (HBM) didasarkan pada pemahaman bahwa seseorang akan mengambil tindakan yang berhubungan dengan kesehatan berdasarkan persepsi dan kepercayaannya, dengan mendasarkan pada 6 aspek pemikiran individu yang akan mempengaruhi pengambilan keputusan dalam diri individu tersebut untuk menentukan apa yang baik bagi dirinya (Green \& Murphy, 2014; Hochbaum, Rosenstock, \& Kegels, 1952; Seale et al., 2020). Enam aspek pemikiran tersebut yaitu: perceived susceptibility (kerentanan yang dirasakan); perceived severity (bahaya/kesakitan yang dirasakan); perceived benefit (manfaat yang dirasakan); perceived barrier (hambatan yang dirasakan;) modifying variable (variabel modifikasi) dan cues to action (isyarat untuk bertindak).

Empat konstruk utama dari persepsi dapat dimodifikasi oleh variabel lain seperti budaya, tingkat pendidikan, pengalaman masa lampau, keterampilan, tingkat social ekonomi, norma dan motivasi. Variabel tersebut adalah karakteristik individu yang akan mempengaruhi persepsi pribadi. Dalam HBM, ada juga perilaku yang dipengaruhi oleh isyarat untuk bertindak (cues to action), yakni peristiwa-peristiwa, orang, atau hal-hal yang menggerakkkan orang untuk mengubah perilaku mereka (Bish \& Michie, 2010; Carpenter, 2010; Ertmer \& Ottenbreit-Leftwich, 2010; Gallotti et al., 2020; Liao, Xu, Wang, \& Liu, 2017; Taylor, Landry, Paluszek, \& Asmundson, 2020). Hal ini dapat berasal dari informasi media massa, nasihat dari orang lain, pengalaman pribadi, hasil pengamatan, dan artikel.

Masyarakat kurang memiliki pemahaman seberapa rentan mereka tertular Covid19, seberapa parah penyakit ini, apa manfaat melakukan pencegahan, dan kurangnya petunjuk untuk bertindak. Masyarakat menghadapi berbagai hambatan untuk mengakses fasilitas kesehatan. Hal ini menyebabkan terjadinya salah persepsi terkait self-efficacy: mereka tidak yakin akan kemampuan dan tindakannya. Pemerintah masih belum optimal dalam membangun kesadaran masyarakat terhadap bahaya wabah dan kemudahan akses kesehatan. Dalam komunikasi terkait wabah, pemerintah masih menggunakan istilah rumit dan hanya mudah dipahami oleh masyarakat perkotaan terdidik yang berasal dari kelas menengah.

Pejabat pemerintah bahkan bisa mengeluarkan pernyataan berbeda-beda, padahal keadaan darurat membutuhkan komunikasi yang komprehensif dan konsisten. Keengganan pemerintah melaksanakan Pembatasan Sosial Berskala Besar (PSBB) dengan sungguh-sungguh. Penduduk miskin mengalami kesulitan untuk mendapatkan tes Covid-19 secara mandiri karena biaya yang relatif mahal, sehingga masyarakat menengah ke bawah menjadi lebih rentan. Pemerintah hanya menyediakan tes gratis di rumah sakit bagi mereka yang pernah kontak dengan kasus positif atau mengunjungi daerah berisiko dan menunjukkan gejala klinis Covid-19. Padahal beberapa kasus terbukti tanpa gejala umum.

\section{Peranan Media dalam Pembentukan Persepsi}

Dalam menghadapi pandemic ini, penting bagi pemerintah untuk transparan dan menyampaikan informasi yang jelas dan jujur kepada public. Kebingungan publik membuat warga tidak siap untuk memerangi krisis kesehatan publik. Selain itu, berbahaya bagi politisi untuk mempolitisasi pandemi ini. Pada saat seperti ini, pesan dari pimpinan pemerintah perlu konsisten agar publik bisa mendapatkan kembali kepercayaan pada pemerintahan. Pemerintah dan tokoh di media harus memanfaatkan pengetahuan para ahli, terutama dari Pusat Penelitian Penyakit dan WHO, dan secara akurat menyampaikan informasi dengan bijaksana dan tepat agar tidak menimbulkan kepanikan di kalangan masyarakat.

Sama seperti virus korona itu sendiri, informasi yang salah telah menyebar jauh dan luas, menenggelamkan sumber informasi yang kredibel (Gallotti et al., 2020; Gregory \& Leo, 2003; Kamel Boulos \& Geraghty, 2020; Malecki, Keating, \& Safdar, 
2020). Beberapa bulan terakhir, postingan dari WHO dan Pusat Kontrol Penyakit AS (CDCP) secara kumulatif hanya mencapai ratusan ribu respon, jauh di bawah respon terhadap situs teori hoax dan konspirasi, yang telah direspon lebih dari 52 juta. Hal ini menunjukkan bahwa sumber informasi yang belum terverifikasi menjadi rujukan masyarakat karena popularitasnya, sehingga sangat penting untuk kita belajar dari kesalahan masa lalu, dan media memiliki peran besar untuk mewujudkan hal ini.

Dalam rangka meningkatkan jumlah pemirsa, organisasi media besar membuat berita utama yang dramatis tetapi malah memicu kepanikan di masyarakat. Saat tenaga kesehatan masih mempelajari tentang virus, media sudah mulai berspekulasi tentang potensi dampak kesehatan yang disebabkan oleh virus, kemudian mempublikasikan potensi efek terburuk dari virus tersebut, sehingga memicu kepanikan di masyarakat umum. Informasi yang salah ini sebagian besar berasal dari akun media sosial dan situs web tanpa bukti yang kredibel untuk mendukung klaim mereka (Citation, 2004; Dani \& Mediantara, 2020; Gao et al., 2020; Kadarisman, 2019; Pennycook, McPhetres, Zhang, Lu, \& Rand, 2020). Disinilah manejemen risiko dibutuhkan.

Manajemen risiko (Jardine et al., 2003; Massaro et al., 2018; Rogers et al., 2020) dimulai dengan kesadaran dan tujuan. Manajemen efektif dari risiko epidemik penyakit menular baru, pada fase dimana belum ada pengobatan atau vaksinasi mungkin sebagian besar tergantung pada perilaku pencegahan dari populasi. Penerapan perilaku kehati-hatian sangat bergantung pada komunikasi risiko (Infanti, Sixsmith, Barry, Núñez-Córdoba, \& Guillén-Grima, 2013; Lohiniva et al., 2020; Malecki et al., 2020; Organization, 2020; Rogers et al., 2020) yang efektif, yaitu komunikasi yang menimbulkan persepsi risiko realistis, pengetahuan dan keterampilan yang benar untuk mempromosikan dan mengaktifkan praktik kehati-hatian (Brug, Aro, \& Richardus, 2009).

Kesehatan manusia berhubungan dengan kesehatan hewan, yang dapat menjadi ancaman penyakit menular baru atau emerging infectious diseases. Untuk menangani hal tersebut diperlukan suatu pendekatan dimana interaksi dalam lingkungan dapat terjalin, yang disebut dengan One Heath. Pendekatan ini melibatkan pendekatan kolaboratif, multisektoral, baik di tingkat lokal, regional, nasional hingga global, dan bertujuan mencapai hasil kesehatan yang optimal mengenai hubungan antara manusia dan lingkungan dengan tidak merugikan satu sama lain. Sinergitas pemajuan upaya kesehatan yang diwujudkan melalui peningkatkan upaya kesehatan masyarakat, memperluas basis pengetahuan ilmiah serta meningkatkan pendidikan dan pemahaman serta kerjasama antara pemerintah sebagai pembuat kebijakan, masyarakat sebagai pendukung kebijakan dibantu berbagai program ekologi untuk menjamin kesehatan manusia, hewan dan lingkungan. Peranan komunitas atau kelompok-kelompok masyarakat untuk berpartisipasi aktif adalam upaya pencegahan dan penanggulangan penyakit menular ini sangat penting dan strategis karena masyarakat yang menjadi pendukung, selaku obyek dan subyek program pemerintah.

\section{SIMPULAN}

Beberapa simpulan yang dapat ditarik dari kajian mengenai persepsi terhadap risiko pandemic ini adalah: (1) Manajemen persepsi dan manajemen pemberitaan yang konsisten serta kredibel merupakan kebutuhan yang sangat penting ; (2) Kesiapsiagaan terhadap potensi pandemi, membutuhkan kerjasama, koordinasi dan pengelolaan hubungan antar berbagai sektor dan actor; serta (3) Pendekatan One Health berbasis komunitas sangat penting untuk mengurangi risiko 


\section{DAFTAR PUSTAKA}

Ahmad, N., Ahmad, W., Arman, R., Rahimi, W., Ahmadi, A., Shahabzada, S. M., \& Raghavan, V. (2020). Community Perception Survey - COVID 19: Knowledge, Attitude and Practice Survey in Kabul, Kunduz and Khost Provinces. The Johanniter International Assistance, (April), 1-31. Retrieved from https://www.humanitarianresponse.info/sites/www.humanitarianresponse.info/file s/assessments/afg_community_perception_survey_Covid19_final_report_johanniter_20042020.pdf

Anderson, R. M., Heesterbeek, $\bar{H}$., Klinkenberg, D., \& Hollingsworth, T. D. (2020). How will country-based mitigation measures influence the course of the COVID-19 epidemic? The Lancet, 395(10228), 931-934. https://doi.org/10.1016/S01406736(20)30567-5

Assessment, R. (2018). RISK ASSESSMENT: PANDEMIC RISK ASSESSMENT: PANDEMIC, 1-26.

Bahasa, P. (2016). Kamus Besar Bahasa Indonesia Online. Dalam Http://Kbbi. Web. Id/Dekat, Diakses Tanggal, 15.

Bai, Z., Gong, Y., Tian, X., Cao, Y., Liu, W., \& Li, J. (2020). The Rapid Assessment and Early Warning Models for COVID-19. Virologica Sinica, 35(3), 272-279. https://doi.org/10.1007/s12250-020-00219-0

Bish, A., \& Michie, S. (2010). Demographic and attitudinal determinants of protective behaviours during a pandemic: A review. British Journal of Health Psychology, 15(4), 797-824. https://doi.org/10.1348/135910710X485826

Brug, J., Aro, A. R., \& Richardus, J. H. (2009). Risk perceptions and behaviour: Towards pandemic control of emerging infectious diseases: lional research on risk perception in the control of emerging infectious diseases. International Journal of Behavioral Medicine, 16(1), 3-6. https://doi.org/10.1007/s12529-0089000-x

Buana, R. D. (2017). Analisis Perilaku Masyarakat Indonesia dalam Menghadapi Pandemi Covid-19 dan Kiat Menjaga Kesejahteraan Jiwa. Sosial Dan Budaya, Fakultas Syariah Dan Hukum Universitas Islam Negeri (UIN) Syarif Hidayatullah Jakarta, 53(9), 1689-1699. https://doi.org/10.1017/CBO9781107415324.004

Carpenter, C. J. (2010). A meta-analysis of the effectiveness of health belief model variables in predicting behavior. Health Communication, 25(8), 661-669.

Citation, S. (2004). Learning from SARS. Learning from SARS. https://doi.org/10.17226/10915

Currie, C. S. M., Fowler, J. W., Kotiadis, K., Monks, T., Onggo, B. S., Robertson, D. A., \& Tako, A. A. (2020). How simulation modelling can help reduce the impact of COVID-19. Journal of Simulation, 14(2), 83-97. https://doi.org/10.1080/17477778.2020.1751570

Dai, N. F. (2020). Stigma Masyarakat terhadap Pandemi Covid-19. Prosiding Nasional Covid-19, 66-73.

Dani, J. A., \& Mediantara, Y. (2020). Covid-19 dan Perubahan Komunikasi Sosial. Persepsi: Communication Journal, 3(1), 94-102.

de Zwart, O., Veldhuijzen, I. K., Richardus, J. H., \& Brug, J. (2010). Monitoring of risk perceptions and correlates of precautionary behaviour related to human avian influenza during 2006 - 2007 in the Netherlands: Results of seven consecutive surveys. BMC Infectious Diseases, 10, 1-15. https://doi.org/10.1186/1471-2334$10-114$

Ding, Y., Du, X., Li, Q., Zhang, M., Zhang, Q., Tan, X., \& Liu, Q. (2020). Risk perception of coronavirus disease 2019 (COVID-19) and its related factors among college students in China during quarantine. PloS One, 15(8), e0237626. https://doi.org/10.1371/journal.pone.0237626 
Ertmer, P. A., \& Ottenbreit-Leftwich, A. T. (2010). Teacher technology change: How knowledge, confidence, beliefs, and culture intersect. Journal of Research on Technology in Education, 42(3), 255-284.

Gallotti, R., Valle, F., Castaldo, N., Sacco, P., \& De Domenico, M. (2020). Assessing the risks of "infodemics" in response to COVID-19 epidemics. https://doi.org/10.1101/2020.04.08.20057968

Gao, J., Zheng, P., Jia, Y., Chen, H., Mao, Y., Chen, S., ... Dai, J. (2020). Mental health problems and social media exposure during COVID-19 outbreak. Plos One, 15(4), e0231924.

Gostic, K., Gomez, A. C. R., Mummah, R. O., Kucharski, A. J., \& Lloyd-Smith, J. O. (2020). Estimated effectiveness of symptom and risk screening to prevent the spread of COVID-19. Elife, 9, e55570.

Green, E. C., \& Murphy, E. (2014). Health belief model. The Wiley Blackwell Encyclopedia of Health, Illness, Behavior, and Society, 766-769.

Gregory, G. D., \& Leo, M. Di. (2003). Repeated behavior and environmental psychology: the role of personal involvement and habit formation in explaining water consumption 1. Journal of Applied Social Psychology, 33(6), 1261-1296.

Hochbaum, G., Rosenstock, I., \& Kegels, S. (1952). Health belief model. United States Public Health Service, 1.

Infanti, J. J., Sixsmith, J., Barry, M. M., Núñez-Córdoba, J. M. C. O.-O., \& GuillénGrima, F. (2013). Effective risk communication for the prevention and control of communicable diseases in Europe. European Centre for Disease Prevention and Control, (10.2900/64747), 1-16. https://doi.org/10.2900/64747

Jardine, C. G., Hrudey, S. E., Shortreed, J. H., Craig, L., Krewski, D., Furgal, C., \& Mc Coll, S. (2003). Risk Management Frameworks for Human Health and Environmental Risks. Journal of Toxicology and Environmental Health - Part B: Critical Reviews, 6(6), 569-718. https://doi.org/10.1080/10937400390208608

Jones, K. E., Patel, N. G., Levy, M. A., Storeygard, A., Balk, D., Gittleman, J. L., \& Daszak, P. (2008). Global trends in emerging infectious diseases. Nature, 451(7181), 990-993. https://doi.org/10.1038/nature06536

Kadarisman, A. (2019). Peran Generasi Muda dalam Pemanfaatan Media Sosial untuk Mempromosikan Geopark Ciletuh. Ultimacomm: Jurnal IImu Komunikasi, 11(2), 92-108.

Kamel Boulos, M. N., \& Geraghty, E. M. (2020). Geographical tracking and mapping of coronavirus disease COVID-19/severe acute respiratory syndrome coronavirus 2 (SARS-CoV-2) epidemic and associated events around the world: How 21st century GIS technologies are supporting the global fight against outbr. International Journal of Health Geographics, 19(1), 1-12. https://doi.org/10.1186/s12942-020-00202-8

Liao, Y., Xu, B., Wang, J., \& Liu, X. (2017). A new method for assessing the risk of infectious disease outbreak. Scientific Reports, 7(December 2016), 1-12. https://doi.org/10.1038/srep40084

Liliana Cori 1, , , F. B. 1, \& Anthonj, E. C. 2 and C. (1993). Risk Perception and. Engineering, 183-203.

Lohiniva, A.-L., Sane, J., Sibenberg, K., Puumalainen, T., \& Salminen, M. (2020). Understanding coronavirus disease (COVID-19) risk perceptions among the public to enhance risk communication efforts: a practical approach for outbreaks, Finland, February 2020. Eurosurveillance, 25(13), 2000317.

Malecki, K., Keating, J. A., \& Safdar, N. (2020). Crisis communication and public perception of COVID-19 risk in the era of social media. Clinical Infectious Diseases. 
Massaro, E., Ganin, A., Perra, N., Linkov, I., \& Vespignani, A. (2018). Resilience management during large-scale epidemic outbreaks. Scientific Reports, 8(1). https://doi.org/10.1038/s41598-018-19706-2

Motta Zanin, G., Gentile, E., Parisi, A., \& Spasiano, D. (2020). A Preliminary Evaluation of the Public Risk Perception Related to the COVID-19 Health Emergency in Italy. International Journal of Environmental Research and Public Health, 17(9), 3024.

Olga, J. (2014). Pandemic Risk. Finance and Development, 51(4), 16-17. Retrieved from

https://www.worldbank.org/content/dam/Worldbank/document/HDN/Health/WDR1 4 bp_Pandemic_Risk_Jonas.pdf

Organization, W. H. (2020). Risk communication and community engagement readiness and response to coronavirus disease (COVID-19): interim guidance, 19 March 2020. World Health Organization.

Otálora, M. M. C. (2020). Yuliana. Parque de Los Afectos. Jóvenes Que Cuentan, 2(February), 124-137. https://doi.org/10.2307/j.ctvzxxb18.12

Pennycook, G., McPhetres, J., Zhang, Y., Lu, J. G., \& Rand, D. G. (2020). Fighting COVID-19 misinformation on social media: Experimental evidence for a scalable accuracy-nudge intervention. Psychological Science, 31(7), 770-780.

Priyoto. (2014). Teori Sikap \& Perilaku dalam Kesehatan, Dilengkapi Contoh Kuesioner. Yogyarkarta: Nuha Medika.

Robbins, S. P. (2002). Prinsip-prinsip perilaku organisasi. Jakarta: Erlangga.

Rogers, D. P., Anderson-Berry, L., Bogdanova, A.-M., Fleming, G., Gitay, H., Kahandawa, S., ... Wang, W. (2020). Learning from Multi-Hazard Early Warning Systems to Respond to Pandemics [ 1 ] Learning from Multi-Hazard Early Warning Systems to Respond to Pandemics, 1-20. Retrieved from https://ec.europa.eu/jrc/en/publication/recommendations-national-riskassessment-disas-

Rothan, H. A., \& Byrareddy, S. N. (2020). The epidemiology and pathogenesis of coronavirus disease (COVID-19) outbreak. Journal of Autoimmunity, 102433.

Sampurno, M. B. T., Kusumandyoko, T. C., \& Islam, M. A. (2020). Budaya Media Sosial, Edukasi Masyarakat, Dan Pandemi COVID-19. SALAM: Jurnal Sosial Dan Budaya Syar-I, 7(5).

Seale, H., Heywood, A. E., Leask, J., Sheel, M., Thomas, S., Durrheim, D. N., ... Kaur, R. (2020). COVID-19 is rapidly changing: Examining public perceptions and behaviors in response to this evolving pandemic. PLOS ONE, 15(6 June), 1-13. https://doi.org/10.1371/journal.pone.0235112

Shammi, M., Bodrud-Doza, M., Towfiqul Islam, A. R. M., \& Rahman, M. M. (2020). COVID-19 pandemic, socioeconomic crisis and human stress in resource-limited settings: A case from Bangladesh. Heliyon, 6(5). https://doi.org/10.1016/j.heliyon.2020.e04063

Shook, N. J., Sevi, B., Lee, J., Oosterhoff, B., \& Fitzgerald, H. N. (2020). Disease avoidance in the time of COVID-19: The behavioral immune system is associated with concern and preventative health behaviors. PloS One, 15(8), e0238015. https://doi.org/10.1371/journal.pone.0238015

Sjöberg, L. (2000). <Sj-berg-2000-Risk_Analysis.pdf>, 20(1).

Taylor, S., Landry, C. A., Paluszek, M. M., \& Asmundson, G. J. G. (2020). Reactions to COVID-19: Differential Predictors of Distress, Avoidance, and Disregard for Social Distancing. Journal of Affective Disorders. https://doi.org/10.1016/j.jad.2020.08.002 